\title{
PENGGALIAN IDE MELALUI PENGEMBANGAN BERPIKIR KRITIS BERDASARKAN GAMBAR BERTEMA DALAM PEMBELAJARAN MENULIS CERPEN
}

\author{
Hari Sunaryo ${ }^{1}$, Eggy Fajar Andalas ${ }^{2}$, Hari Windu Asrini ${ }^{3}$, Candra Rahma W. P. ${ }^{4}$ \\ FKIP Universitas Muhammadiyah Malang ${ }^{1}$ \\ Surel: harinaryo@ymail.com ${ }^{1}$ \\ andalaseggy@gmail.com ${ }^{2}$ \\ hariwindu_asrini@yahoo.co.id ${ }^{3}$ \\ candrac07@gmail.com ${ }^{4}$
}

\begin{abstract}
Abstrak
Penelitian ini bertujuan untuk meningkatkan kemampuan penggalian ide dalam proses penulisan cerita pendek dengan menggunakan media gambar bertema. Desain penelitian yang digunakan adalah Penelitian Tindakan Kelas. Subjek penelitian ini adalah siswa kelas X IPA II SMAN 9 Malang berjumlah 31 siswa, dengan rincian 12 siswa perempuan, 29 siswa laki-laki, dan guru. Sumber data penelitian tindakan kelas ini meliputi 1) peristiwa pembelajaran menulis cerita pendek, 2) narasumber, dan 3) dokumen. Teknik pengumpulan data yang digunakan dalam penelitian ini adalah observasi, wawancara, dan studi dokumen. Teknik analisis data yang digunakan adalah teknik analisis kritis, yaitu teknik analisis yang bermaksud mengungkap kekurangan dan kelebihan kinerja siswa selama proses pembelajaran dilakukan. Analisis kritis dilakukan terhadap aspek 1) ide sesuai tema tugas, 2) ide bersifat baru, 3) ide cerita kontekstual, dan 4) ide cerita aktual. Hasil penelitian menunjukkan pada siklus I peningkatan kriterita ketuntatasan minimal (KKM) sebesar 25,8\% dari sebelumnya $38,7 \%$ pada pra-tindakan. Melalui penerapan pada siklus II diperoleh hasil peningkatan pada kualitas proses pembelajaran dan hasil. Nilai yang diperoleh pada siklus ini meningkat menjadi $83,8 \%$ dan nilai ini sudah melampaui KKM dan ketuntasan klasikal mencapai $75 \%$.
\end{abstract}

Kata Kunci: penggalian ide; pengembangan berpikir kritis; gambar bertema; pembeajaran; menulis cerpen

\section{Jurnal Ilmiah \\ Pendidikan Bahasa, Sastra Abstract Daerah}

This research aim to improve the ability to extract ideas in the process of short story writing using themed image media. The research design used is action research. The data used are process data and result data. The research subjects were 31 students of class X IPA II Malang, 12 female students, 29 male students, and teachers. The sources of data are learning events writing short stories, informant \& responden, and documents. Data collection techniques used in this study were observation, interviews, and document studies. The data analysis technique used is critical analysis technique, which is an analytical technique that intends to reveal the weaknesses and strengths of student performance during the learning process. 
Critical analysis is carried out on aspects 1) ideas according to the theme of the task, 2) new ideas, 3) contextual story ideas, and 4) actual story ideas. The results of the study showed that in the first cycle the increase in the minimum limitation criteria (KKM) was $25.8 \%$ from the previous $38.7 \%$ in the pre-action. Through the application of the second cycle results were obtained by increasing the quality of the learning process and results. The value obtained in this cycle increased to $83.8 \%$ and this value has exceeded KKM and classical completeness reached $75 \%$.

Keywords: extracting ideas; development of critical thinking; themed images; learning; write short stories

\section{PENDAHULUAN}

Tidak dapat dipungkiri bahwa aktivitas menulis merupakan jenis aktivitas pembelajaran yang paling tidak disukai oleh siswa. Meskipun begitu studi yang dilakukan dalam kurun waktu 20 tahun terakhir, terdapat tiga studi dalam skala besar yang dilakukan oleh Astin (1992), Light (2001), dan Arum \& Roksa (2011), memperlihatkan bahwa menulis dapat meningkatkan kualitas pembelajaran. Bahkan Light (2001:55) mengemukakan hal yang cukup mengejutkan, yaitu semakin banyak jumlah tulisan yang dihasilkan siswa dalam suatu proses pembelajaran lebih berpengaruh kuat terhadap hasil pembelajaran yang efektif dibandingkan dengan model pembelajaran yang lain. Meskipun begitu, terdapat juga hasil-hasil penelitian lain yang dilakukan oleh Schumacher \& Nash (1991), Ackerman (1993), dan Ochsner \& Fowler (2004), yang menentang klaim tersebut.nDe ngan menggunakan model penelitian kuasi-eksperimental skala kecil, mereka menentang klaim bahwa menulis dapat meningkatkan pembelajaran.

Berdasarkan pada hasil-hasil studi tersebut dapat dipahami bahwa terdapat dua paradigma besar dalam menyikapi peranan menulis dalam proses pembelajaran siswa. Meskipun begitu, tidak dapat dipungkiri bahwa menulis tidak saja berkaitan dengan aspek fisik, tetapi juga mental. Menulis tentang pikiran dan perasaan terdalam mengenai suatu kejadian atau pengalaman akan memberikan dampak positif dan kesehatan jiwa yang lebih baik kepada penulisnya (Hernowo, 2003:38). Selain hal tersebut, dalam proses pembelajaran di kelas keterlibatan secara aktif siswa dalam bentuk atktivitas produktif akan membangkitkan pemikiran kritis tingkat tinggi, membantu siswa bergumul secara produktif pada pertanyaanpertanyaan kritis, dan dapat membangkitkan refleksi diri yang mengarah pada pembelajaran yang lebih terintegrasi dan bermakna secara pribadi (Bean, 2011:2).

Di Indonesia, aktivitas menulis dalam proses pembelajaran selalu disematkan pada mata pelajaran Bahasa Indonesia. Meskipun dapat dikatakan sebagai satu-satunya mata pelajaran yang diidentikkan dengan tulis menulis, pembelajaran yang dilakukan di sekolah, utamanya mata pelajaran sastra Indonesia, hanya berorientasi pada model pembelajaran yang menitikberatkan pada pemahaman teori-teori sastra. Tidak ayal kemudian mata pelajaran sastra yang seharusnya berkutat pada persoalan pengolahan rasa dan estetika pada siswa menjadi sebuah model pembela- 
jaran yang disamakan dengan mata pelajaran lain. Siswa diberikan pengenalan-pengenalan teori yang sedikit banyak kurang bersentuhan langsung dengan aspek kemanusiaan yang sejatinya menjadi esensi dalam pembelajaran sastra. Sebagai akibatnya muncul stigma dalam diri siswa mengenai sulitnya pelajaran sastra, utamanya penulisan cerpen, sehingga siswa merasa hal tersebut relatif kurang berguna bagi kehidupannya kelak.

Dalam implementasinya di sekolah, siswa sering menganggap bahwa karya sastra merupakan materi yang sulit untuk dimengerti, sehingga sebagian guru enggan mengajarkan dan mengambil jalan pintas dengan mengajarkan teori-teori sastra (Ariadinata, 2006:23). Hal tersebut dianggap sebagai sebuah win-win solution di tengah pembelajaran sastra yang dipersepsi sebagai hal yang sulit untuk dipelajari. Bahkan tidak jarang banyak guru yang menggunakan model-model tes dalam bentuk teori dengan minimnya praktik, apresiasi, bahkan kreasi (Yuniarti, Slamet, \& Setiawan, 2013:126).

Berbagai hal tersebut merupakan hal yang terjadi dalam pembelajaran Bahasa Indonesia di kelas X IPA II SMA Negeri 9 Malang. Berdasarkan observasi yang dilakukan oleh peneliti pada selasa, 31 Juli 2018, terlihat bahwa dalam proses pembelajaran sastra yang dilakukan di kelas, proses pembelajaran masih terpusat pada guru. Guru menerangkan unsur intrinsik sebuah karya sastra dengan menggunakan konsep-konsep teoretis, seperti tema, alur, tokoh, penokohan, dan lain-lain dalam bentuk power point. Pada proses pembelajaran yang berlangsung tampak guru lebih mendominasi jalannya pembelajaran. Selain itu, berdasarkan hasil wawancara dengan guru diperoleh keterangan bahwa sejatinya guru juga mengeluhkan mengenai metode yang cocok digunakan dalam pembelajaran menulis cerita pendek kepada siswa. Selama ini proses pembelajaran yang dilakukan lebih mengede-pankan aspek pengenalan teori-teori dan kurangnya penekanan pada pendekatan praktik yang berorientasi pada proses kreatif penulisan.

Berbagai persoalan yang dihadapi oleh guru dan siswa dalam penulisan cerita pendek adalah penggalian ide cerita. Penggalian ide cerita merupakan bagian yang sangat penting karena proses kreatif penulisan sastra bermula pada hal ini. Berdasarkan angket yang diberikan kepada siswa, $80 \%$ siswa menyatakan bahwa persoalan penggalian ide dasar cerita penulisan cerita pendek merupakan masalah utama yang dihadapinya dalam mata pelajaran menulis cerita pendek. Selain itu, guru juga menuturkan hal yang sama bahwa permasalahan mencari ide cerita dan mengembangkannya menjadi sebuah cerita pendek merupakan kendala utama yang dihadapi oleh para siswa. Untuk menyikapi permasalahan tersebut diperlukan suatu metode yang dapat meningkatkan kualitas pembelajaran menulis cerita pendek. Dengan peningkatan kualitas pembelajaran yang lebih baik diharapkan dapat meningkatkan kemampuan menulis cerita pendek oleh siswa $\mathrm{X}$ IPA SMAN 9 Malang.

\section{METODE}

Penelitian ini dilakukan di SMAN 9 Malang, khususnya di kelas X IPA 
II. Penelitian dilakukan dalam kurun waktu 1 bulan, yaitu bulan 31 Juli hingga 30 Agustus 2018. Penelitian yang digunakan adalah penelitian tindakan kelas yang melibatkan kolaborasi peneliti, guru, dan siswa untuk menciptakan pembelajaran yang lebih baik. Model penelitian ini digunakan untuk memecahkan permasalahan penelitian yang telah disampaikan, yaitu me-ningkatkan kemampuan menulis cerita pendek siswa dengan penerapan metode penggalian ide dengan metode berpikir kritis dengan gambar bertema.

Untuk merealisasikan hal tersebut digunakan metode deskriptif-kualitatif dengan tujuan menggambarkan kenyataan di lapangan, yaitu proses pembelajaran menulis cerita pendek sebelum dan sesudah diberi tindakan berupa penerapan metode penggalian ide melalui berpikir kritis dengan gambar bertema.

Subjek penelitian ini adalah siswa kelas X IPA II SMAN 9 Malang berjumlah 31 siswa, dengan rincian 12 siswa perempuan dan 29 siswa lakilaki. Selain siswa subjek penelitian ini adalah guru mata pelajaran Bahasa Indonesia kelas X IPA II, yaitu Ibu Anik Sri Utami, S.Pd.

Sumber data penelitian tindakan kelas ini meliputi 1) peristiwa pembelajaran menulis cerita pendek, 2) nara sumber, dan 3) dokumen. Pertama, persitiwa pembelajaran menulis cerpen digunakan sebagai sumber data untuk menghimpun data observasi yang dilakukan oleh peneliti di kelas X IPA II SMAN 9 Malang baik sebelum tindakan mupaun setelah tindakan pada setiap siklusnya. Data awal hasil observasi dilakukan pada tanggal 31 Juli 2018. Data observasi peristiwa dengan metode penggalian ide melalui berpikir kritis dengan gambar bertema pada siklus I dilakukan pada Selasa 16 Agustus 2018 dan Kamis 21 Agustus 2018. Pada siklus II obervasi terhadap peristiwa pembelajaran dilakukan pada Selasa, 28 Agustus 2018. Kedua, narasumber penelitian ini ada dua, yaitu guru bertindak sebagai informan dan seluruh siswa sebagai responden. Data informan digunakan mengumpulkan data tentang 1) pelaksanaan pembelajaran menulis cerita pendek sebelum metode penggalian ide melalui berpikir kritis dengan gambar bertema dilakukan, 2) kesulitan-kesulitan yang dihadapi, dan 3) pelaksanaan pembelajaran dengan menggunakan gambar bertema serta hambatan-hambatannya. Data responden yang berasal dari siswa dikumpulkan melalui angket mengenai 1) pengetahuan dan pengalaman dasar siswa tentang penulisan cerpen sebelumnya, 2) tanggapan siswa tentang penerapan metode penggalian ide melalui pengembangan berpikir kritis dengan gambar bertema. Ketiga, dokumen yang dikumpulkan berupa 1) rencana pelaksanaan pembelajaran (RPP), 2) hasil karya siswa berupa cerita pendek, 3) foto kegiatan pembelajaran, 4) hasil angket yang diisi siswa, dan 4) hasil wawan-

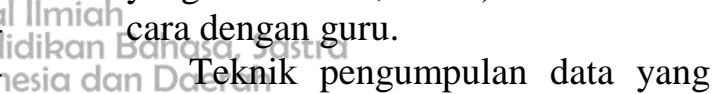
digunakan dalam penelitian ini adalah observasi, wawancara, dan studi dokumen.

Teknik analisis data yang digunakan adalah teknik analisis kritis, yaitu teknik analisis yang bermaksud mengungkap kekurangan dan kelebihan kinerja siswa selama proses pembelajaran dilakukan. Analisis kritis dilakukan terhadap aspek 1) ide sesuai te- 
ma tugas, 2) ide bersifat baru, 3) ide cerita kontekstual, dan 4) ide cerita aktual.

Prosedur penelitian dilakukan dengan langkah-langkah 1) persiapan, 2) studi awal, 3) pelaksanaan, dan 4) penyusunan laporan. Pelaksanaan siklus meliputi 1) perencanaan tindakan, 2) pelaksanaan tindakan, 3) pengematan, dan 4) refleksi. Banyaknya siklus yang dilakukan dalam penelitian ini adalah II siklus. Hal tersebut mengingat bahwa siklus terakhir telah mencapai capaian yang telah ditetapkan.

\section{HASIL DAN PEMBAHASAN}

Berdasarkan tujuan penelitian yang telah disampaikan sebelumnya, berikut hasil peneleitian penerapan metode penggalian ide melalui pengembangan berpikir kritis dengan gambar bertema dalam pembelajaran menulis cerita pendek pada siswa SMAN 9 Malang kelas X IPA II.

\section{Penerapan Metode Penggalian Ide dengan Gambar Bertema}

Berdasarkan pada hasil wawancara, angket, dan observasi awal diperoleh hasil bahwa minat dan motivasi siswa dalam pembelajaran menulis cerita pendek masih rendah. Terdapat beberapa faktor yang mempengaruhi hal tersebut. Pertama, berdasarkan data angket diperoleh hasil bahwa se bagian besar siswa mengaku bahwa sebelumnya mereka sudah pernah membaca cerita pendek sebelumnya (70\%). Bahkan, sebagian besar siswa (80\%) telah membaca lebih dari 5-6 judul karya prosa (baik cerita pendek maupun novel). Artinya, pengetahuan awal siswa terhadap bentuk dan gaya penceritaan dalam cerita pendek telah diketahuinya. Cerita pendek bukanlah sebuah hal yang baru bagi mereka. Meskipun begitu ditemui fakta lain, bahwa sebagian besar siswa $(75 \%)$ membaca cerita tersebut melalui buku-buku pelajaran. Artinya, mereka hanya membaca ketika disuruh guru atau pembahasan materi pelajaran saja. Di luar itu, hanya terdapat 7 siswa yang mengaku membaca cerita pendek di luar buku pelajaran. Kondisi ini memperlihatkan bahwa intensitas perkenalan dan penikmatan pembacaan karya sastra yang dilakukan oleh siswa hanya didasarkan pada kebutuhan pelajaran saja. Di luar itu mereka kurang tertarik terhadap karya sastra.

Kondisi yang terjadi tersebut berbanding lurus dengan hasil wawancara yang dilakukan dengan guru mata pelajaran. Guru mengaku bahwa dalam proses pembelajaran yang dilakukan, banyak dari siswa yang tidak mengenal dengan baik cerita-cerita pendek karya sastrawan Indonesia. Bahkan untuk cerita pendek yang sangat terkenal di Indonesia. Akibatnya, dalam proses pembelajaran guru sering kesulitan dalam membicarakan judul dan isi karya sastra kepada siswanya. Sebagai akibatnya, teks cerita yang terdapat dalam buku-buku pelajaran merupakan sumber acuan utama dalam pembahasan yang dila-

Illmiah kukan dikelas.
idikan Bdingustar huan siswa terhadap minat dalam penulisan cerita pendekpun terlihat. Sebanyak 12 siswa mengaku pernah menulis sebuah cerita pendek sebelumnya. Meskipun begitu, hampir semua siswa, baik yang sudah pernah menulis ataupun belum menulis, mengaku pencarian ide penulisan cerita merupakan hal yang paling sulit untuk dilakukan. Mereka sering kesulitan 
untuk menentukan dan merumuskan ide dasar yang akan digunakan sebagai bahan penulisan cerita pendek.

Kondisi tersebut juga ditunjang dengan hasil obervasi yang memperlihatkan bahwa dalam proses pembelajaran cerita pendek di kelas, siswa lebih banyak diberikan porsi pembelajarna materi-materi yang sifatnya teoretis, dibandingkan dengan materi yang bersifat kritis yang akan membangitkan daya imajinasinya dalam penggalian ide sebuah cerita. Dalam metode pembelajaran konvensional yang diterapkan ini, siswa juga terlihat pasif dalam pembelajaran karena hanya mendengarkan dan mengingatingat materi pembelajaran yang bersifat text-book-oriented.

Berdasarkan hasil tersebut dapat disimpulkan bahwa perlunya perubahan paradigma pada proses pembelajaran yang dilakukan. Hal tersebut memperlihatkan bahwa terdapat kaitan yang erat antara proses pembelajaran dengan hasil yang diperoleh. Guru hendaknya harus mau dan mampu mengubah paradigma pembelajaran yang dilakukannya sesuai dengan tuntutan dan perkembangan zaman.

Berdasarkan hal tersebut tindakan yang dilakukan dalam penelitian ini adalah penerapan metode penggalian ide melalui pengembangan berpikir kritis dengan gambar bertema dalam penulisan cerita pendek siswa. Dengan penerapan metode tersebut dapat menjadikan siswa aktif dalam proses pembelajaran, adanya keterlibatan langsung siswa dan pendidik, dan proses penggalian ide cerita tidak lagi menjadi persoalan yang sulit, tetapi justru menyenangkan dan mudah.

Metode ini telah dierapkan dalam pembelajaran menulis cerita pendek melalui tindakan sebanyak dua siklus. Berdasarkan hasil observasi dan hasil tes yang telah dilakukan pada siklus I dan II pembelajaran menulis cerita pendek mengalami peningkatan. Peningkatan tersebut mencakup kualitas proses pembelajaran dan peningkatan kemampuan penggalian ide cerita pendek siswa SMAN 9 Malang kelas IPA II.

\section{Pembahasan Persiklus}

Pada siklus I diterpakan metode penggalian ide cerita dengan gambar bertema kepada 31 siswa SMAN 9 Malang kelas X IPA II. Pada siklus ini digunakan 3 gambar, yaitu 1) seorang anak kecil berpakaian lusuh berdiri di tengah-tengah tumpukan sampah, 2) rumah gubuk di bawah jembatan layang kota, dan 3) seorang kakekkakek berpakaian lusuh dan membawa sebuah karung sedang menggendong anak kecil kurus kering berpakaian lusuh sedang menyeberang jalan raya. Melalui proses tersebut dilakukan penerapan metode dengan proses pembelajaran penggalian ide secara kritis dengan meminta keterlibatan secara aktif siswa untuk mengemukakan pendapatnya mengenai peristiwa pada gambar sesuai interpretasinya. Dalam proses ini model gambar yang digunakan seperti ilustrasi berikut.

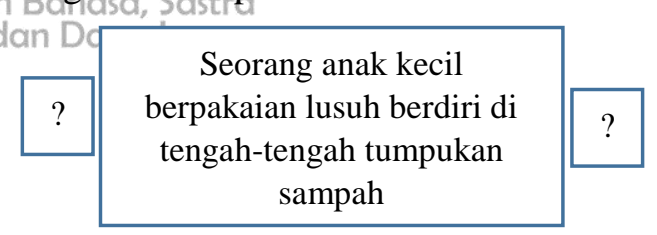

Melalui gambar tersebut siswa diminta untuk menginterpretasikan sesuai imajinasinya mengenai peristiwa sebelum dan setelah gambar. Melalui metode ini diperoleh suatu 
pembelajaran kolaboratif yang melibatkan keterlibatan aktif siswa untuk berlomba-lomba menginterpretasikan hasil pemikirannya. Tidak jarang terjadi perdebatan dan diskusi yang cukup alot di antara siswa.

Berdasarkan metode yang dilakukan, diperoleh hasil bahwa $64,5 \%$ siswa dapat mencapai di atas KKM, yaitu 70, sedangkan $35,5 \%$ siswa lainnya memperoleh nilai di bawah KKM. Siswa-siswa tersebut mampu mengaktualisasikan hasil interpretasi lisannya ke dalam bentuk rancangan ide penulisan cerita pendek karyanya sendiri. Dalam proses pembelajaran ini diperoleh peningkatan kriterita ketuntatasan minimal (KKM) sebesar $25,8 \%$ dari sebelumnya $38,7 \%$ pada pratindakan. Setelah dilakukan analisis dan evaluasi kekurangan pada siklus satu dilakukan siklus II.

Pada siklus II, diterapakan kembali metode penggalian ide dengan gambar bertema, tetapi dengan sedikit modifikasi, yaitu 1) perubahan pada gambar yang lebih dekat dengan kehidupan siswa serta adanya kisi-kisi berupa konteks yang melatarbelakangi peristiwa pada gambar. Kisi-kisi yang diberikan kepada siswa berupa bantuan pengembangan gagasan yang dikemukakan oleh siswa, seperti penjelasan mengenai bangunan atau peristiwa yang ada pada gambar. Dilakukan juga penjelasan-penjelasan lanjutan kepada siswa mengenai, jika terdapat gambar perumahan elit maka berkaitan dengan kehidu-pan orang kaya, dan lain-lain. Setiap gambar yang disajikan kepada siswa diberikan konteks-konteks lanjutan yang memancing daya berpikir kritis siswa untuk mengemukakan interpretasi lanjutan dari kisi-kisi yang telah diberikan. Melau penerapan pada siklus II diperoleh hasil peningkatan pada kualitas proses pembelajaran dan hasil. Nilai yang diperoleh pada siklus ini meningkat menjadi $83,8 \%$ dan nilai ini sudah melampaui KKM dan ketuntasan klasikal mencapai 75\% sehingga penelitian tindakan kelas yang dilakukan dinyatakan berhasil.

\section{PENUTUP \\ Simpulan}

Berdasarkan hasil Penelitian Tindakan Kelas yang dilakukan pada siswa kelas X IPA II SMAN 9 Malang pada materi penulisan cerita pendek dengan menggunakan metode penggalian ide melalui berpikir kritis dengan gambar bertema diperoleh kesimpulan bahwa penerapan model ini dapat meningkatkan kualitas kemampuan menulis cerita pendek siswa. Hal tersebut terefleksikan dari hasil siklus I peningkatan kriterita ketuntatasan minimal (KKM) sebesar 25,8\% dari sebelumnya $38,7 \%$ pada pratindakan. Melaui penerpan pada siklus II diperoleh hasil penin-katan pada kualitas proses pembelajaran dan hasil. Nilai yang diperoleh pada siklus ini meningkat menjadi $83,8 \%$ dan nilai ini sudah melampaui KKM dan ketuntasan klasikal mencapai $75 \%$.

\section{DAFTAR PUSTAKA}

Ackerman, J. M. 1993. The Promise of Writing to Learn. Written Communication, 10, 334-370.

Ariadinata. 2006. Pengajaran Sastra di Sekolah. Jakarta: Gramedia.

Arum, R., \& Roksa, J. 2011. Academically Adrift: Limited Learning in College Campuses. Chicago: University of Chicago Press.

Astin, A. W. 1992. What Really Matters in General Education: Provo- 
cative Findings form a National Survey of Student Outcomes. Perspective, 22, 23-46.

Bean, J. C. 2011. Engaging Ideas: The Professors Guide to Integrating Writing, Critical Thinking, and Active Learning in the Classroom (2nd ed.). San Francisco: JosseyBass.

Hernowo. 2003. Quantum Writing. Yogyakarta: MLC.

Light, R. 2001. Making the Most of College: Students Speak Their Minds. Cambridge: Harvard University Press.

Ochsner, R., \& J, F. 2004. Playing Devil's Advocate: Evaluating the Literature of the WAC/WID movement. Review of Educational Research, 74, 117-140.

Schumacher, G. M., \& Nash, J. G. 1991. Conceptualizing and Measuring Knowledge Change due to Writing. Research in the Teaching of English, 25, 67-96.

Yuniarti, N., Slamet, Y., \& Setiawan, B. 2013. Peningkatan Kualitas Pembelajaran dan Kemampuan Menulis Cerita Pendek dengan Menggunakan Metode Peta Pikiran (Mind Mapping) pada SIswa Kelas IX A SMP Negeri 9 Pontianak. Jurnal Pendidikan Bahasal Ilmiah dan Sastra, 1(1), 125-139. Pendidikan Bahasa, Sastra 